\title{
Revisiting Official History in Evangel Athial's Hitler and the \\ Decline of Shah Dynasty
}

\author{
Raj Kishor Singh, $\mathrm{PhD}^{*}$
}

\begin{abstract}
This article aims to analyze Athial's Hitler and the Decline of Shah Dynasty to prove that the author reimagines and rewrites official history in his novel with combination and blurring of fact and fiction. It is studied from theoretical parameters of historiographic metafiction. Through an amalgamation of fact and fiction, the novel challenges the traditional version of the official history of Nepal and Germany. The subjectivity inherent in historiographic narratives is further explored through Athial's representation of historical character Hitler in the novel. The presence of major characters creates confusion about the nature of the novel as a work of fiction or as historiographic account. Through the use of irony and supernatural elements, Hitler and the Decline of Shah Dynasty becomes a parody of historiographic narratives which claim to be objective. The blurring of the boundaries between fiction and history and constructedness of history through discourse is the main idea in this paper. The writer imitates the genre of the historical novel but reveals its limitations and corresponds to what Linda Hutcheon calls historiographic metafiction. The novel mines the elements of the then history of Hitler, Germany, and Nepalese Shah Dynasty with the personal history of the author to revise and redefine the official version of history. This revisiting of mainstream history helps to establish the notion of plurality of historical accounts and a rejection of objectivity in historical writings. This novel has metafictional mode of writing, and the author represents metafictional parody in which historical incidents are repeated with a difference to show that history is discourse and is always open to interpretation.
\end{abstract}

Keywords: history and fiction, official history, rewriting, blurring of boundaries, plurality, metafiction

${ }^{*}$ Dr. Singh has been working as Lecturer in English at the Central Department of English, Tribhuvan University, Kirtipur, Nepal. 


\section{Introduction}

The present paper tries to analyze Evangel Athial's novel, Hitler and the Decline of Shah Dynasty and expose how the novel chronicles the historical facts related with Hitler, Germany and Nepalese Shah Dynasty while problematizing both histories through a parallel recounting of the alternative stories depicting love relations, mythical allusions and imaginative expressions. The novel does not only highlight the love story between Alexie and Nalini but also blends this love story with the histories of patriarchy, Hitler's regime and Nepalese Shah dynasty. The paper uses Hayden White's theory of metafiction to challenge the objectivity of history as it is an account of both what is factual and fictional. It serves to challenge the authenticity of official history through a blending of fictional and nonfictional elements. The novel is about the fall of historical events of Hitler's regime and Nepalese Shah dynasty while at the same time referring to black magic, firepuja and the love between Alexie and Nalini. In doing so, it blends what is fictional with the historical resulting in metafictional narrative strategy.

Metafiction is a mode of writing which is often used to problematize the objectivity and authenticity generally associated with traditional linear history. Conventional concept of history valorizes the so-called great events and deeds associated with higher classes and royal families and the rulers which are recorded in historical documents and books on history. Such representations created discourses about specific historical periods that revolved around locations of power. The modernist version of history constructed such official versions of history in the name of purity of historical accounts and narratives. On the contrary, the postmodernist notion of history, influenced by Nietzsche's and Foucault's ideas about history, power and truth, problematize the authenticity of traditional linear history. Hayden White's notion of metafiction or metahistory erodes the notion of linear history by including love, romance, magic, dream and so on in accounts of history. It violates disciplinary boundaries of historical writing and exposes the hybridity inherent in any form of writing.

\section{Textual Analysis}

History and fiction are entwined in Hitler and the Decline of Shah Dynasty which shows that history is fictional and fiction too can be historical. The novel constructs both of them discursively. The novel does so by combining the love story of Nalini and Alexie with the traditional narrative of patriarchy, Hitler's regime and Nepalese Shah Dynasty. The author has attempted to chronicle the historical facts associated with Germany and Nepal. The recounting of Hitler's regime and Nepalese Shah Dynasty also combines what is dreamlike and magical. The authenticity of historical chronicling is problematized by a meaningful blending of history and fiction. The novel fuses history with the love relation between two lovers who belong to two different cultural and 
economic backgrounds. Such a narrative fusion of history and fiction in the novel can only be understood in the light of historiographic metafiction. For Hayden White, "Every history is shaped by its metahistory - that is, the archetypical historical narrative that the historian uses to shape and structure a story about the past. Metahistories are not embedded in the past - they are imposed on the past, to give it continuity, coherence and meaning" (Hayden, 1973, p. 8).

Every history is constructed and shaped by certain rules and regulations. So, White is of the view that there is no identical difference between history and fiction. Jago Morrision's idea, among the features of the novel, "the most striking one is the abrupt ending of the story" supports the idea that a work has no clear goal to move towards. This is a kind of postmodernist position challenging the teleology of a fictional work. As we try to untangle the intertwined relationship between fiction and nonfiction, Athial's own comments remind us that his stories are invented as he remarks," well as you know metafiction is a kind of story telling ... here as a writer I have tried to speak directly to my reader ... in the process I too have become a character" (Athial, 2012, p. $1)$.

These lines bring to light the idea that the author is directly commenting on his work as being metafiction. Though he is a writer, he tries to speak to the readers to make them realize the fictional nature of his own writing through his writing about history. The author also admits that the same story has been told in many ways which shows that the basic story has been fictionalized in various ways. There is no one objective version of history and history does not move towards a single goal and solution. For Linda Hutcheon, "postmodern fiction suggests that to rewrite or represent the past in fiction and in history is, in both cases, to open it up to the present, to prevent it from being conclusive and teleological" (Hutcheon, 1988, p. 209). This kind of remark paves way for a belief in the existence of multiple versions of the same historical events.

The novel begins from the factual setting of Nepal which is the Tribhuvan International Airport in Kathmandu. The writer describes the environment of the airport and the plane of visitor crew moving towards Mount Everest as the narrator describes, "the monsoon clouds were all around ... we looked down to see Kathmandu scurrying away as if offended at our mission"(Athial, 2012, p. 9). Thus, it is evident that the novel begins from the factual setting which is also further suggested by the narrator's statement "eventually we reached Lukla, the Khumbu region of Nepal" (Athial, 2012, p. 9). The historical and factual setting of the novel is combined with the fictional narration of the environment and the people of the location. The comparison of natural beauty of the mountain with the beauty of Nalini in fictional manner indicates the metafictional nature of the novel. 
This novel focuses on the position of fictionalization of history at the ground of postmodern concept of historical novel developed by Linda Hutcheon with supporting insight from Patricia Waugh. Though the writer is narrating his own life experiences and historical incidents with the imaginary stories, the novel can be explored as a Historiographic Metafiction because it depicts both the history of Nepal and of German with facts and fiction. This novel is a postmodern novel, and so it blurs the boundary of fact and fiction because 'history has become more literary and the literature more historicized'.

Historiographic Metafiction term was, introduced by Linda Hutcheon, usefully coined to point self- reflexive commentary on the means and possibility of the historical representation that we see in many contemporary texts. The writer depicts his selfreflexivity, experiences the historically signified events. Since, the postmodern period witnessed many crucial incidents and the writer cannot go beyond the context, in this sense literature is the reflection of society that also acquired contextual historicity. The official history is guided by the power or shaped by the dominant group but Historiographic Metafiction is the new form of postmodern fiction "best be reserved to describe fiction that is at once metafictional and historical in its ethos of the texts and contexts of the past" (Hutcheon, 1988, p. 120). Parody is one of the characteristics of Historiographic Metafiction as Linda Hutcheon claims, "gives way to the celebrated postmodernist 'paradox' "its world is both resolutely fictive and yet undeniable historical" (Hutcheon, 1988, p. 142). Parody is dominant in this novel where the main issue, which cannot be presented explicitly, is shown in paradoxical way to critique the history of Nepal with reference to Hitler.

The narrator has presented a scene of encounter with Nalini in the fictional manner as,

I was as enthusiastic as a cat would be, when encouraged to take cold shower. As the bus took a tedious turn, she swayed against me and I could feel the softness of the young breast on my left arm. This felt much more tempting than history and I moved close applying a slight reverse pressure. The hazel eyes darkened a little before giving me an eloquent look. (Athial, 2012, p. 43)

In his trip to Bhaktapur with Nalini, Alexei feels the acquainted closeness with her while travelling by bus. As the bus jolts, he happens to brush against Nalini's young breast. He narrates this intense feeling of emotion as "much more tempting than history" (Athial, 2012, p. 43). This shows how the author ironizes the history in comparison with the personal feelings and emotions. This shows how postmodernist works of art reveal a desire to understand present culture as the product of previous representations. Thus, postmodern art acknowledges and accepts the challenge of tradition: the history of representation cannot be escaped but it can be both explained and commented on critically through irony and parody. 
According to Hutcheon, metafiction breaks the authenticity of the history with the use of fictional elements and it is what the narrator does in the novel. The narrator, Alexie, has mentioned the historical details of how the Mercedes Benz was gifted to the contemporary King of Nepal by Hitler in return of talismanic amulet. According to the narrator, this information is taken from the newspaper article on December 21, 2011: I took out the newspaper from the battered attaché and re-read the news - 'The Mercedes Benz that was presented by Adolf Hitler to the former Nepal Monarch, Tribhuvan Bir Bikram Shah Dev, will be on display at the Narayanhiti Palace, Kathmandu.' NNA, Dec 21, 2011. The image emerged in a very slow motion and soon filled the screen. Hitler's car ... the one gifted to the monarch in return for the Dark Force. (Athial, 2012, p. 13)

Hitler gifted the Mercedes Benz in 1937 and it reached Nepal in 1940. It is a real historical fact but his taking of talismanic amulet as a source of dark force seems imaginary. It shows how fiction's "values and practices are constructed and legitimized" through a blending of fact and imagination that together construct what we call writing (Waugh, 1984, p. 19). Certain works are dubbed with historiographic metafictions because of their conscious self-reflexivity and concern with history. The incident about the king and Hitler may or may not have found its way into mainstream history, but the way it has been casually dealt with in the novel shows how fiction has its own way of dealing with and commenting on what is factual and historical.

In the postmodern period, history and fiction have become the similar kind of genre. Not only history but also fiction also represents the real events of the past and the contemporary period indirectly from which readers can feel the situation what it was and is. Nalini's narration of the past is another example of historiographic metafiction. The places like Moscow, Madrid, Tokyo and Kathmandu are real as well as historical but Nalini's narration of her past lacks the authenticity, which makes it fictional. Her husband as a councilor, her two daughters Rupali and Paru, and others are the fictional elements. This blending of the history and fiction is evident in the following words of Nalini:

His Embassy duties took us to Madrid, Moscow and Tokyo. Rupali was born in Madrid. When I regained conscious, I asked the nurse to bring her. Keeping her cloths to my face I whispered your name in her ears and told her you are a real

Daddy. I could see the tiny leaps moving in a small smile. (Athial, 2012, p. 102) The past is not something escapable, avoidable, or controllable; neither it can be represented or adopted thoroughly. Nevertheless, we have only access to the past through its traces- its documents, the testimony of witness, and other archival materials. That's why; we only have representations of the past from which we can construct our narratives or explanations. These facts are clearly accompanied by Nalini's words 
above. The novel also presents the manifold of historical and factual elements such as the birth date and parents of Hitler. Similarly, Hitler's autobiographical volume Mein Kampf is also real. But the indication of "Hitler's sexual uneasiness and the homosexual tendencies" (Athial, 2012, p. 117) are fictional.

For the critic Pared Campbell, Hitler and the Decline of Shah Dynasty is not only the story of history but simultaneously, a story of marriage, love and Church (Campbell, 2013, p. 94). It is again supported by Adams Kowaleski for whom "the events of Hitler and the Decline of Shah Dynasty are not presented in chronological order. The frequent shifting between a subjective first person narrator and a cold third person narrator in the multitude of voices that we find in the text strengthens its effects" (Kowaleski, 2012, p. 56). Violation of chronology and use of subjective point of view used in a novel about historical events also challenge the objectivity and authenticity of that kind of writing.

The novelist's inclusion of his own father, Christian movement in Nepal and the issue of contemporary king Birendra are other historical incidents. Athial presents the information of his father with the factual setting of Kathmandu in addition to the fictional story of his crush on a university girl:

My father was a missionary priest ... serving in Kathmandu at that time. The church with its residential quarters at Putali Sadak, a busy street between Simha Durbar, the Nepal parliament and Narayanhiti Palace, the abode of the then monarch, His Majesty King Birendra Bir Bikram Shah Dev. I was then a student at the Tribhuvan University and it was here I had met her. (Athial, 2012, p. 14) In this way, fiction can represent reality in an imaginary form. Historical and factual details of locations, activities of Christian missionaries and the accounts of King are presented imaginatively. Alexie also adds some fantastic description about a pretty girl he met on a bus. The fictional description of the girl shows her as:

She looked disarmingly irreproachable and had an eye-catching and mischievous smile on the round face ... for a second I thought she was going to make a pass at me and wondered how to react in such an eventuality (Athial, 2012, p. 15).

This is a good example of how the writer presents his manipulation of history with the exploitation of imagination and fantasy within the narration of fact. In Hutcheon's view, "there is no neat dividing line between the texts of history and literature, and so one feels free to draw on both" (Hutcheon, 1988, p. 136). The blurring of the boundaries between history and fiction illustrates one's mistrust for the objectivity of history and opens up possibilities for the parody of this objective, historical discourse. Susana Onega argues that "historiographic metafiction differs from traditional historical novels in that the former does not seek historical accuracy and realistic verisimilitude but, on the contrary, challenges the repairability of the two discourses" (Onega, 1999, p. 1). 
Traditional fictions do not interrupt the storyline to remind readers that the events are a work of imagination or to comment that the stories have been told before in various ways. As Athial writes about writing, he is building trust between himself and the readers. Although the love story between Alexie and Nalini is told in many different ways, readers trust they are hearing a true story because Athial tells them, "here is what actually happened" (2012, p. 16). The fictional description of Nalini makes her the object of beauty and the source of fictional imagination, "hmm... let me think... I watched her. I was in fascination as the lip went deep into the mouth, slowly came out, and again started the return journey..." $(2012$, p. 20$)$. The author purposefully draws the attention of the readers to the fact that they are reading fiction. This is self-reflexivity in which a work of fiction is conscious of its own status as fiction.

\section{Conclusion}

After applying theoretical parameters of historiographic metafiction to the novel Hitler and the Decline of Shah Dynasty, Athial's sense of parody of historical incidents is very obvious to readers. The novel Hitler and the Decline of Shah Dynasty is a metafictional piece of writing which challenges the objectivity and authenticity of history and blurs the boundary between fact and fiction. It blends historical accounts with imaginative and fantastic elements to draw our attention to the idea that no writing is pure and every mode of writing is hybrid in certain sense. History is neither singular nor factual because there can be many different versions of the same historical events and the subjective and imaginative mind of the author creates some disruptions in objectivity and authenticity of mainstream history. In this metafictional mode of writing, there is parody in which historical incidents are repeated with a difference to show that history is discourse and is always open to interpretation.

\section{References}

Athial, E. (2012). Hitler and the Decline of the Shah Dynasty. New Delhi: Mahaveer Publishers.

Campbell, P. (2013). History and Truth. Ed. Richard Trenner. Ontario: Ontario Review $P$.

Hutcheon, L. (1988). A Poetics of Postmodernism: History, Theory, Fiction. London: Routledge.

Kowaleski, A. (2012). The American Novel. Oklahoma, US: U of Oklahoma P. Morrision, J. (2012). A Spirit of Transgression. New Delhi: Mahaveer Publications. Onega, S. (1999). Metafiction and Myth in the Novels of Peter Acroyd. Columbia:

Camden House. 
Waugh, P. (1984). Metafiction: The Theory and Practice of Self Conscious Fiction. London: Routledge.

White, H. (1973). Metahistory: The Historical Imagination in Nineteenth Century Europe. Baltimore. US: John Hopkins UP. 